\title{
PERANCANGAN ENTERPRISE ARCHITECTURE SISTEM INFORMASI PELAYANAN PUBLIK DI BPN KOTA PEKANBARU
}

\author{
${ }^{1}$ Idria Maita, ${ }^{2}$ Farida Habibah \\ ${ }^{1,2}$ Program Studi Sistem Informasi, Fakultas Sains dan Teknologi UIN Suska Riau \\ Jl. HR Soebrantas, KM. 18.5, No. 155, Simpang Baru, Pekanbaru, Indonesia, 28293. \\ Email: 1idriamaita@gmail.com, ${ }^{2}$ faridahabibah@students.uin-suska.ac.id
}

\begin{abstract}
ABSTRAK
Perancangan enterprise architecture dilakukan untuk meningkatkan operasional dan pelayanan organisasi maupun lembaga pemerintahan serta untuk menyelaraskan kebutuhan informasi dan bisnis. BPN Kota Pekanbaru mempunyai tugas melaksanaknakan tugas pemerintahan di bidang pertanahan. Saat ini BPN Kota Pekanbaru telah memiliki beberapa sistem informasi namun sistem informasi tersebut belum terintegrasi dan belum adanya perencanaan arsitektur. Tujuan dari penelitian ini adalah untuk merancang enterprise arsitektur pada sistem informasi pelayanan publik BPN Kota Pekanbaru menggunakan framework TOGAF ADM. Hasil dari penelitian ini berupa blueprint enterprise architecture pelayanan pertanahan BPN Kota Pekanbaru, diharapkan dapat memberikan gambaran dan acuan dalam mengembangkan sistem informasi pelayanan publik.
\end{abstract}

Kata kunci: enterprise architecture, TOGAF ADM, pelayanan publik, BPN Kota Pekanbaru

\section{A. PENDAHULUAN}

Pada era globalisasi saat ini kebutuhan terhadap penyajian informasi yang cepat dan akurat sehingga perkembangan serta penerapan Teknologi Informasi (TI) di perusahaan maupun instansi pemerintahan berkembang dengan pesat yang bertujuan untuk meningkatkan kualitas pelayanan publik [1]. Untuk melakukan perencanaan terhadap kualitas data dan mencapai misi Sistem Informasi perlu dilakukan perencanaan terhadap arsitektur enterprise yang merupakan proses dalam pendefinisian arsitektur untuk menyelaraskan kebutuhan informasi dan bisnis serta untuk mengimplementasi arsitektur tersebut [2].

Penerapan TI harus memikirkan dan membentuk strategi, struktur, proses, infrastruktur dan model bisnis, untuk mengatasi masalah tersebut organisasi atau perusahaan melakukan perencanaan yang menyeluruh dengan membentuk blueprint arsitektur dan menyelaraskan antara bisnis dan SI/TI [3]. Enterprise Architecture adalah pendekatan yang dapat digunakan untuk mengelola kompleksitas struktur organisasi dan sistem informasi yang berbeda serta memfasilitasi integrasi strategi, personil, bisnis, data dan IT [4].

Badan Pertanahan Nasional Kota Pekanbaru mempunyai tugas untuk melaksanakan tugas pemerintahan di bidang pertanahan secara nasional, regional dan sektoral sesuai dengan ketentuan peraturan perundang-undangan. BPN Kota Pekanbaru melaksanakan pelayana publik terhadap masyarakat yang berupa pelayanan pertanahan [5]. Saat ini diperlukan perhatian terhadap upaya-upaya untuk meningkatkan pelayanan pertanahan tersebut. Menurut Kepmen PAN Nomor 25 tahun 2004, pelayanan publik adalah kegiatan yang dilaksanakan oleh penyelenggara pelayanan publik supaya pemenuhan kebutuhan penerima layanan, maupun dalam rangka pelaksanaan ketentuan peraturan perundang-undangan.

Saat ini untuk membantu pelaksanaan pelayanan publik, BPN Kota Pekanbaru telah menerapkan SI/TI yang berfungsi untuk mendukung tugas pokok dan proses bisnis pelayanan pertanahan. Sistem informasi yang saat ini sudah diterapkan yaitu, aplikasi Sentuh Tanahku untuk sistem pengukuran tanah, Website kantor BPN Kota Pekanbaru sebagai penyedia informasi mengenai pelayanan pertanahan dan aplikasi KKP (Komputerisasi Kegiatan Pertanahan) yang merupakan aplikasi utama dalam melakukan pelayanan publik serta PERMATA yang berfungsi untuk mengecek sertifikat.

Penerapan IT yang dilakukan oleh BPN Kota Pekanbaru saat ini belum menerapkan konsep enterprise architecture serta kurangnya perencanaan terhadap pengembangan sistem informasi pelayanan publik yang mengakibatkan sistem informasi yang ada belum mendukung proses pelayanan pertanahan sesuai dengan tujuan dirancangnya sistem informasi tersebut. Maka dari itu diperlukan sebuah rancangan enterprise architecture sebagai panduan dalam mengembangkan sistem informasi pelayanan publik pada BPN Kota Pekanbaru.

Konsep enterprise architecture saat ini telah banyak digunakan pada sektor publik sebagai metodologi untuk meningkatkan efisiensi sistem dan bisnis termasuk perencanaan strategis dan konsolidasi penyimpanan data [4]. TOGAF ADM dipilih sebagai framework dalam penelitian karena TOGAF merupakan kerangka kerja yang rinci dan fleksibel untuk mengembangkan arsitektur enterprise [6].

Berdasarkan permasalahan latar belakang tersebut, maka studi ini merancang enterprise 
architecture sistem informasi pelayanan publik pada BPN Kota Pekanbaru menggunakan framework TOGAF ADM. Fase pada TOGAF ADM yang digunakan meliputi 6 fase yaitu, Preliminary, Phase A: Architecture Vision, Phase $B$ : Business Architecture, Phase C: Information System Architecture, Phase D: Technology Architecture dan Phase E: Opportunities and Solutions. Perancangan enterprise architcture ini diharapkan dapat memberikan gambaran dan acuan dalam mengembangkan sistem informasi pelayanan publik dari hasil blueprint arsitektur yang dirancang.

\section{B. LANDASAN TEORI \\ B.1. Pelayanan Publik}

Pelayanan adalah proses pemenuhan kebutuhan melalui aktivitas secara langsung, sedangkan publik memiliki arti sebagai masyarakat atau kelompok (groups) yang terikat kesamaan cita-cita, tujuan dan bekerjasama dalam mencapai tujuan [7]. Menurut Undang-undang No. 25 tahun 2009 pelayanan publik merupakan kegiatan atau rangkaian kebutuhan pelayanan sesuai dengan peraturan perudang-undangan atas barang dan jasa. Pelayanan publik juga diartikan sebagai pelayanan administratif yang disediakan oleh penyelenggara pelayanan publik bagi setiap warga negara dan penduduk di setiap negara tersebut.

\section{B.2. Enterprise Architecture}

Enterprise Architecture (EA) merupakan sebuah pendekatan untuk mengelola kompleksitas struktur organisasi, lingkungan bisnis, dan sistem informasi yang berbeda dan untuk memfasilitasi integrasi strategi, bisnis, data dan IT [5]. EA memberikan gambaran beberapa model arsitektur yaitu: Arsitektur bisnis, Arsitektur Informasi, Arsitektur Sistem informasi dan Arsitektur Teknologi [7].

\section{B.3. TOGAF ADM}

The Open Group Framework (TOGAF) adalah profil enterprise architecture yang menyediakan metode dan alat (tools) untuk mendukung pengembangan arsitektur [6]. TOGAF memberikan rincian mengenai bagaimana gambaran spesifik dalam sebuah proses pengembangan enterprise architecutre [8]. TOGAF ADM merupakan salah satu stuktur dan komponen yang dimiliki oleh TOGAF [9]. TOGAF ADM adalah metode umum (generic) yang berisi sekumpulan aktivitas yang mempresentasikan progresi dari setiap fase dan model arsitektur yang digunakan serta dibuat selama tahap pegembangan sistem informasi [10]. TOGAF ADM memiliki 10 fase yang dapat dilihat pada Gambar 1.

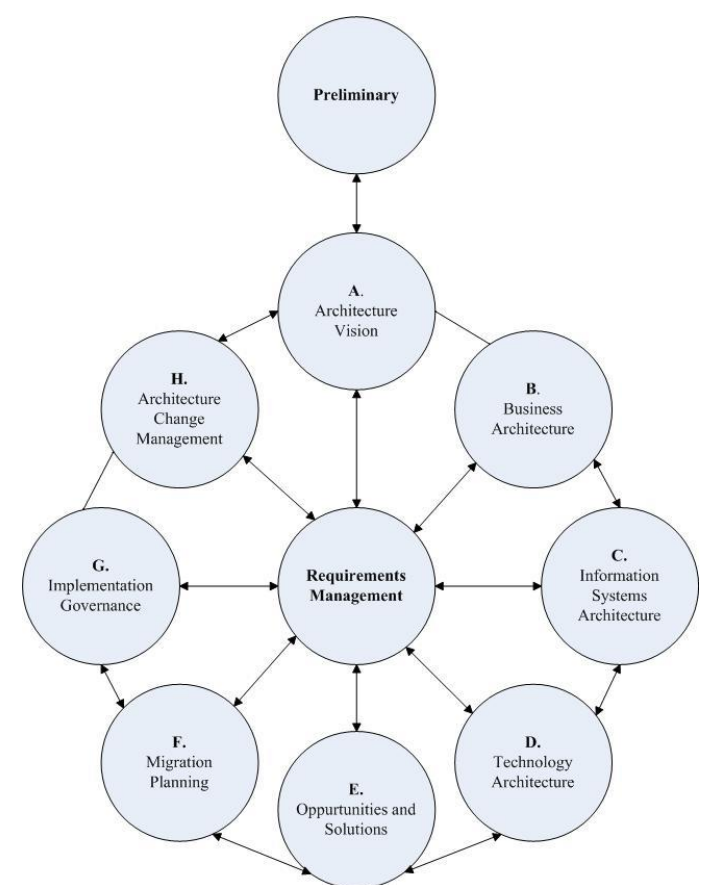

Gambar 1 Fase Togaf ADM

a. Preliminary

Fase Preliminary atau fase perencanaan adalah fase persiapan awal dalam merancangan sebuah arsitektur enterprise dan mengkonfirmasi komitmen dari stakeholder, penentuan framework dan metodologi yang akan digunakan [11]. Tujun dari fase preliminary yaitu, untuk mempersiapkan perusahaan untuk merealisasikan pekerjaan arsitektur [12].

b. Phase A: Architrcture Vison

Pada fase architecture vision atau visi arsitektur berisikan pertanyaan-pertanhaan yang diajukan untuk mendapatkan arsitektur yang idela seperti profil organisasi, visi dan misi organisasi, tujuan organisasi, sasaran organisasi, proses bisnis organisasi, unit organisasi serta kondisi arsitektur saat ini [13].

c. Phase B: Business Architecture

Fase business architecture (arsitektur bisnis) akan mendefinisikan kondisi awal dari arsitektur bisnis, menentukan model bisnis serta aktivitas bisnis yang diinginkan berdasarkan skenario bisnis [11].

d. Phase C: Information System Architecture Fase information system architecture atau arsitektur sistem informasi terdiri dari dua bagian yaitu arsitektur aplikasi dan arsitektur data. Arsitektur sistem informasi menjebatani pandangan antara bisnis dan terjemahan fisiknya, mendefinisikan komponen perangkat lunak yang bertujaun mendukung realisasi bisnis dan sistem informasi [13].

e. Phase D: Technology Architecture 
Fase technology architecture (arsitektur teknologi) bertujuan untuk mengembangkan arsitektur teknologi yang diinginkan sesuai dengan arsitektur data dan aplikasi yang meliputi: perangkat lunak (software), perangkat keras (hardware) [13].

f. Phase E: Opportunities and Solutions

Fase opportunities and solution (peluang dan solusi) bertujuan untuk melakukan evaluasi dan memilih cara pengimplementasi, mengidentifikasi parameter strategis untuk perubahan perhitunagn cost (biaya) dan benefit dari proyek serta menghasilkan rencana implementasi secara keseluruhan [11].

g. Phase F: Migration Planning

Fase migration planning bertujuan untuk memilih proyek implementasi yang menjadi urutan prioritas.

h. Phase G: Implementation Governance

Pada fase implementation governance proyek implementasi akan dilaksanakan sebagai program rencana kerja serta pengelolaan proyek untuk mencapai keberhasilan suatu arsitektur yang diinginkan.

i. Phase H: Architecture Change Management Fase architecture change management akan ditentukan prosedur untuk mengelola perubahan ke arsitektur baru dengan tujuan memastikan bahwa siklus hidup arsitektur dipertahankan. Tahapan ini menetapkan bahwa tata kelola kerangka kerja arsitektur dijalankan dan memastikan kemampuan arsitektur perusahaan memenuhi persyaratan saat ini.

j. $\quad$ Requirement Management

Fase requirement management memiliki tujuan untuk menentukan kebutuhan arsitektur enterprise.

\section{METODOLOGI PENELITIAN \\ C.1. Perencanaan}

Pada tahap perencanaan dilakukan identifikasi terhadap permasalahan yang terjadi. Tahap ini dilakukan dengan cara wawancara dan observasi terhadap objek penelitian. Wawancara dilakukakan dengan Kepala Seksi Penetapan Hak Tanah dan Pemberdayaan Masyarakat dan Kepala Kasubag TU serta dilakukan obeservasi pada loket pelayanan BPN Kota Pekanbaru. Kegiatan wawancara dan observasi juga menghasilkan data primer dan data sekunder untuk kebutuhan penelitian.

\section{C.2. Analisis}

Tahap analisis dimulai dari melakukan analisis terhadap kondisi saat ini yang meliputi kondisi SI/TI dan analisis permasalahan pada BPN Kota Pekanbaru. Selanjutnya dilakukan analisis terhadap baseline arsitektur yang ada saat ini pada BPN Kota Pekanbaru.

\section{C.3. Perancangan Enterprise Architecture}

Pada tahap ini dilakukan pemodelan arsitektur dengan menggunakan 6 fase pada framework TOGAF ADM yang meliputi Preliminary, Phase A: Architecture Vision, Phase B: Business Architecture, Phase C: Information System Architecture, Phase D: Technology Architecture dan Phase E: Opportunities And Solution. Tools yang digunakan pada tahap ini untuk masingmasing fase TOGAF ADM yaitu: Principle Catalog, Identifikasi 5W+1H, Value Chain, Stakeholder Map Matrik, Flowchart, Tree diagram, Use Case Diagram, Class Diagram, Data Desemination Diagram, Application Portofolio Catalog, Technology Portofolio Catalog dan Gap Analysis serta Analysis Matrik.

\section{ANALYSIS DAN HASIL \\ D.1. Preliminary Phase}

Pada fase ini memiliki beberapa tahapan yaitu, menentukan prinsip dari perancangan enterprise architecture dengan menggunakan tools principle catalog dan mengidentifikasi $5 \mathrm{~W}+1 \mathrm{H}$ untuk mengidentifikasi objek perancangan enterprise architecture. Perancangan prinsip EA dapat dilihat pada Tabel 1 yang merupakan priciple catalog dan Tabel 2 merupakan analisis identifikasi $5 \mathrm{~W}+1 \mathrm{H}$ pada Sistem Informasi Pelayanan Publik BPN Kota Pekanbaru.

Tabel 1. Principle Catalog

\begin{tabular}{|c|c|c|}
\hline $\begin{array}{l}\text { Katagori } \\
\text { Prinsip }\end{array}$ & Prinsip & Deskripsi \\
\hline \multirow{13}{*}{$\begin{array}{l}\text { Business } \\
\text { Principle }\end{array}$} & Keutamaan & Prinsip-prinsip \\
\hline & Prinsip & $\begin{array}{l}\text { manajemen informasi } \\
\text { berlaku untuk semua } \\
\text { pihak stakeholder pada } \\
\text { BPN Kota Pekanbaru. } \\
\text { Semua pihak yang } \\
\text { terlibat wajib untuk } \\
\text { mematuhi prinsip- } \\
\text { prinsip yang ada. }\end{array}$ \\
\hline & Memaksimalkan & Keputusan manajemen \\
\hline & Pemanfaatan & informasi dibuat untuk \\
\hline & Enterprise & memberikan manfaat \\
\hline & & $\begin{array}{l}\text { kepada BPN Kota } \\
\text { Pekanbaru }\end{array}$ \\
\hline & Keberlangsungan & Kegiatan pelayanan \\
\hline & Bisnis & $\begin{array}{l}\text { pertanahan BPN Kota } \\
\text { Pekanbaru } \\
\text { berdasar sesuai hukum } \\
\text { dan jauh dari iterupsi/ } \\
\text { gangguan. }\end{array}$ \\
\hline & Kepatuhan & Proses manajemen \\
\hline & Hukum & informasi yang ada pada \\
\hline & & $\begin{array}{l}\text { BPN Kota Pekanbaru } \\
\text { harus mematuhi hukum, } \\
\text { kebijakan dan peraturan } \\
\text { yang ada. }\end{array}$ \\
\hline & $\begin{array}{l}\text { Tanggung Jawab } \\
\text { IT }\end{array}$ & $\begin{array}{lr}\text { Organisasi } & \text { TI } \\
\text { bertanggung } & \text { jawab }\end{array}$ \\
\hline & & $\begin{array}{l}\text { untuk memiliki dan } \\
\text { menerapkan proses } \mathrm{TI} \\
\text { dan infrastruktur yang }\end{array}$ \\
\hline
\end{tabular}




\begin{tabular}{|c|c|c|}
\hline $\begin{array}{l}\text { Katagori } \\
\text { Prinsip }\end{array}$ & Prinsip & Deskripsi \\
\hline \multirow{7}{*}{$\begin{array}{l}\text { Data } \\
\text { Principle }\end{array}$} & & $\begin{array}{l}\text { memenuhi kebutuhan } \\
\text { yang telah ditetapkan. }\end{array}$ \\
\hline & Data Aset & $\begin{array}{l}\text { Data merupakan asset } \\
\text { yang memiliki nilai } \\
\text { untuk perusahaan. }\end{array}$ \\
\hline & Akses Data & $\begin{array}{ll}\text { User memiliki akses ke } \\
\text { data yang diperlukan } \\
\text { untuk } & \text { melakukan }\end{array}$ \\
\hline & & $\begin{array}{lr}\text { aktivitas } & \text { bisnis } \\
\text { organisasi } & \text { sehingga }\end{array}$ \\
\hline & & $\begin{array}{l}\text { dapat dibagi/sharing ke } \\
\text { seluruh user didalam } \\
\text { organisasi. }\end{array}$ \\
\hline & Validasi Data & $\begin{array}{l}\text { Setiap user memiliki } \\
\text { tanggung jawab atas data } \\
\text { yang di-input. }\end{array}$ \\
\hline & Keamanan Data & $\begin{array}{l}\text { Data hanya dapat } \\
\text { diakses user yang } \\
\text { memiliki hak akses. }\end{array}$ \\
\hline \multirow{4}{*}{$\begin{array}{l}\text { Application } \\
\text { Principle }\end{array}$} & Easy Of Use & Aplikasi mudah \\
\hline & & $\begin{array}{l}\text { digunakan sehingga } \text { user } \\
\text { dengan mudah } \\
\text { mengoperasikan aplikasi } \\
\text { (friendly) }\end{array}$ \\
\hline & Kemandirian & Aplikasi dapat \\
\hline & Aplikasi & $\begin{array}{l}\text { digunakan di berbagai } \\
\text { platform teknologi }\end{array}$ \\
\hline \multirow{6}{*}{$\begin{array}{l}\text { Technology } \\
\text { Principle }\end{array}$} & Interoperability & Software dan hardware \\
\hline & & $\begin{array}{l}\text { harus sesuai dengan } \\
\text { kebutuhan aplikasi dan } \\
\text { standar yang ditetapkan. }\end{array}$ \\
\hline & Responsif & Perubahan platform \\
\hline & Terhadap & teknologi harus dapat \\
\hline & Perubahan & diimplementasikan \\
\hline & Manajemen & dengan cepat dan tepat. \\
\hline
\end{tabular}

Tabel 2. Identifikasi $5 \mathrm{~W}+1 \mathrm{H}$

\begin{tabular}{lll}
\hline No. & Driver & Deskripsi \\
\hline 1. & What & Objek: Lingkup Arsitektur. \\
& & Deskripsi: Pelayanan Pertanahan BPN \\
& Kota Pekanbaru. \\
2. Who & Objek: actor yang terlibat dalam \\
& & pemodelan enterprise architecture. \\
& Deskripsi: \\
& - Pemodelan: Farida Habibah.
\end{tabular}

$\begin{array}{ll}\text { 3. Where } & \text { Objek: Lokasi Penelitian } \\ & \text { Deskripsi: BPN Kota Pekanbaru Jl. Naga }\end{array}$

4. When Objek: Waktu penyelesaian.

5. Why Objek: Mengapa perancangan arsitektur ini dibuat.

Deskripsi: Agar pengembangan sistem informasi sesuai dengan kebutuhan dan mendukung proses bisnis pelayanan pertanahan.

6. How Objek: Bagaimana cara merancang arsitektur enterprise pada sistem informasi pelayanan publik.

Deskripsi: Perancangan enterprise architecture dibuat menggunakan TOGAF ADM.

\section{D.2. Phase A: Architecture Vision}

Pada fase architecture vision dilakukan penentuan visi dari arsitektur pelayanan publik BPN Kota Pekanbaru yaitu pelayanan pertanahan dan melakukan analisis value chain terhadap aktivitas bisnis pada BPN Kota Pekanbaru. Kemudian memetakan stakeholder yang terlibat pada aktivitas pelayanan pertanahan menggunakan stakeholder map matrik dan membuat hubungan aktivitas dengan stakeholder.

Visi dari BPN Kota Pekanbaru yaitu, "Menjadi lembaga yang mampu mewujudkan tanah dan pertanahan untuk sebesar-besar kemakmuran rakyat, serta keadilan dan keberlanjutan sistem kemasyarakatan, kebangsaan dan kenegaraan Republik 'indonesia. Gambar 2 merupakan hasil analisis value chain terhadap aktivitas bisnis pada BPN Kota Pekanbaru.

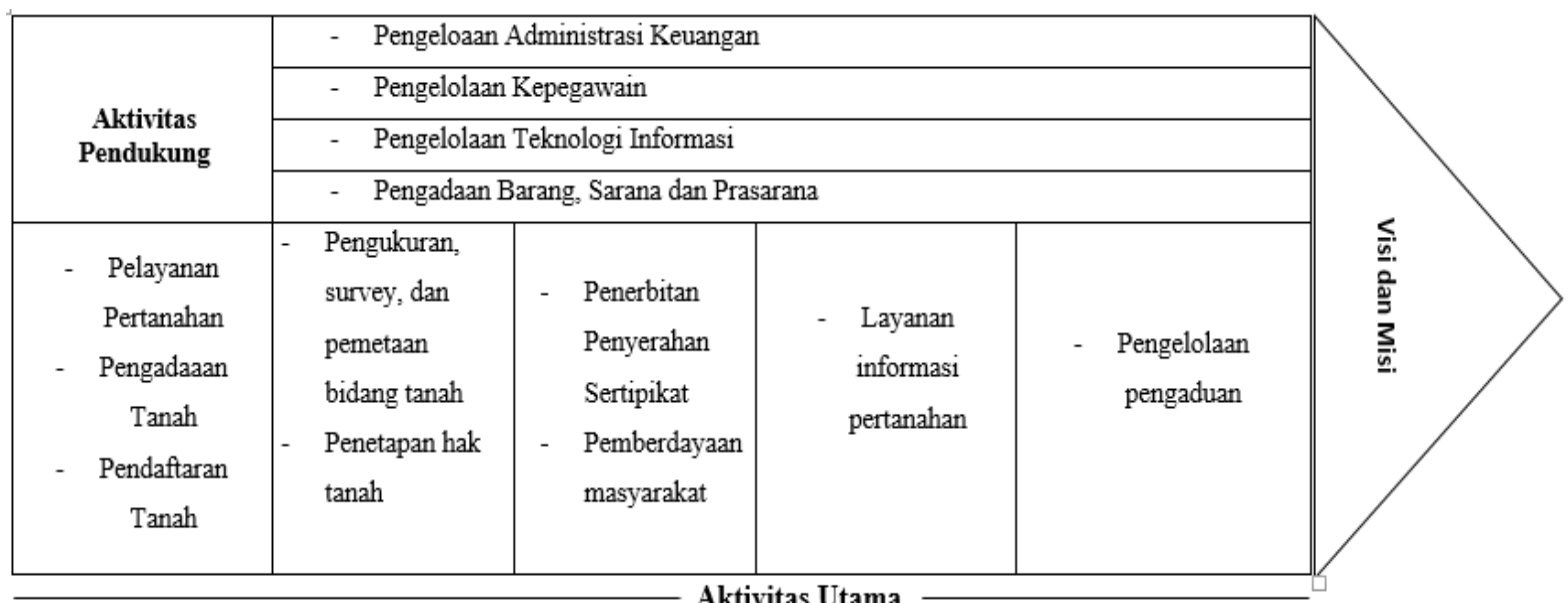

Gambar 2. Analisis Value Chain

\section{D.3. Phase B: Business Architecture}

Pada fase ini dilakukan analisis terhadap proses bisnis yang ada saat ini pada BPN Kota
Pekanbaru dengan membuat flowchart (diagram alir), kemudian melakukan pemetaan tehadap layanan bisnis proses bisnis dan fungsi bisnis pada 
BPN Kota Pekanbaru menggunakan tools archimate. Setelah dilakukan analisis proses bisnis saat ini dan pemetaan proses bisnis maka dibuat rancangan arsitektur bisnis yang dapat dilihat pada Tabel 3.

Tabel 3. Rancangan Business Architecture Usulan

\begin{tabular}{|c|c|c|c|}
\hline No. & Bagian & Kendala & Solusi \\
\hline 1. & $\begin{array}{l}\text { Pelayanan } \\
\text { Pertanahan }\end{array}$ & $\begin{array}{l}\text { Pelayanan masih } \\
\text { dilakukan secara } \\
\text { manual dan } \\
\text { membutuhkan } \\
\text { waktu yang } \\
\text { sangat lama. }\end{array}$ & $\begin{array}{l}\text { Perancangan } \\
\text { aplikasi } \\
\text { pendaftaran } \\
\text { pelayanan online. }\end{array}$ \\
\hline 2. & $\begin{array}{l}\text { Pengukuran } \\
\text { Survey dan } \\
\text { Pemetaan } \\
\text { Bidang } \\
\text { Tanah }\end{array}$ & $\begin{array}{l}\text { Surat tugas } \\
\text { pengukuran } \\
\text { belum } \\
\text { terakomodasi } \\
\text { dengan baik. }\end{array}$ & $\begin{array}{l}\text { Perancangan } \\
\text { sistem } \\
\text { pengelolaan surat } \\
\text { untuk } \\
\text { mengakomodasik } \\
\text { an surat tugas } \\
\text { kepada panitia } \\
\text { pelaksana } \\
\text { pengukuran. }\end{array}$ \\
\hline 3. & $\begin{array}{l}\text { Informasi } \\
\text { pertanahan }\end{array}$ & $\begin{array}{l}\text { Informasi masih } \\
\text { sulit didaptkan } \\
\text { dan harus } \\
\text { melakukan } \\
\text { pendaftaran serta } \\
\text { mengikuti antrian } \\
\text { untuk } \\
\text { mendapatkan } \\
\text { informasi. }\end{array}$ & $\begin{array}{l}\text { Pengembangan } \\
\text { sistem layanan } \\
\text { informasi } \\
\text { pertanahan. } \\
\text { Sistem } \\
\text { terintergrasi } \\
\text { antar seksi } \\
\text { pertanahan. }\end{array}$ \\
\hline 4. & $\begin{array}{l}\text { Pengelolaan } \\
\text { pengaduan }\end{array}$ & $\begin{array}{l}\text { Pengelolaan } \\
\text { pengaduan masih } \\
\text { secara terpusat di } \\
\text { BPN RI . }\end{array}$ & $\begin{array}{l}\text { Perancangan } \\
\text { aplikasi } \\
\text { pengaduan BPN } \\
\text { Kota Pekanbaru . }\end{array}$ \\
\hline
\end{tabular}

\section{D.4. Phase C: Information System Architecture}

Fase ini bertujuan untuk membuat pemodelan arsitektur sistem informasi yang terbagi menjadi dua yaitu application architecture (arsitektur aplikasi) dan data architecture (arsitektur data).

\section{D.4.1. Application Architecture}

Pada fase ini dilakukan analisis terhadap kondisi arsitektur aplikasi saat ini pada BPN Kota Pekanbaru menggunakan Application Portofolio Catalog yang dapat dilihat pada Tabel 4 .

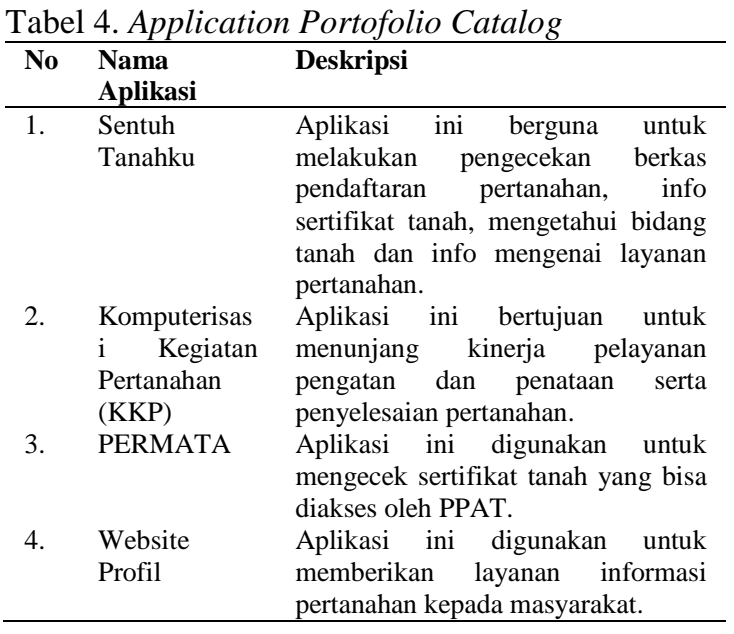

Kemudian membuat rancangan arsitektur aplikasi usulan dengan membuat kandidat aplikasi usulan seperti Tabel 5.

Tabel 5. Kandidat Aplikasi

\begin{tabular}{|c|c|c|}
\hline No & Kandidat Aplikasi & Deskripsi \\
\hline 1. & $\begin{array}{l}\text { Sistem Informasi } \\
\text { Pendaftaran layanan } \\
\text { online }\end{array}$ & $\begin{array}{l}\text { Aplikasi ini mencangkup } \\
\text { proses pendaftaran dan upload } \\
\text { berkas persyaratan }\end{array}$ \\
\hline 2. & $\begin{array}{l}\text { Sistem Informasi } \\
\text { Pengelolaan Surat }\end{array}$ & $\begin{array}{l}\text { Aplikasi ini mencakup } \\
\text { pengelolaan surat tugas } \\
\text { pegukuran }\end{array}$ \\
\hline 3. & $\begin{array}{l}\text { Sistem Informasi } \\
\text { Pengaduan }\end{array}$ & $\begin{array}{l}\text { Aplikasi ini mencakup } \\
\text { pengelolaan } \\
\text { perihal pertanahan }\end{array}$ \\
\hline
\end{tabular}

\section{D.4.2. Data Architecture}

Pada fase ini diidentifikasi struktur data yang diperlukan pada setiap aplikasi pelayanan pertanahan BPN Kota Pekanbaru, melakukan analisis data saat ini menggunakan data dessimination diagram. Setelah melakukan analisis terhadap baseline arsitektur data maka dibuat usulan rancanagan arsitektur data menggunakan class diagram pada Gambar 3. 
Jurnal Ilmiah Rekayasa dan Manajemen Sistem Informasi, Vol. 6, No. 1, Februari 2020, Hal. 6-15 e-ISSN 2502-8995 p-ISSN 2460-8181

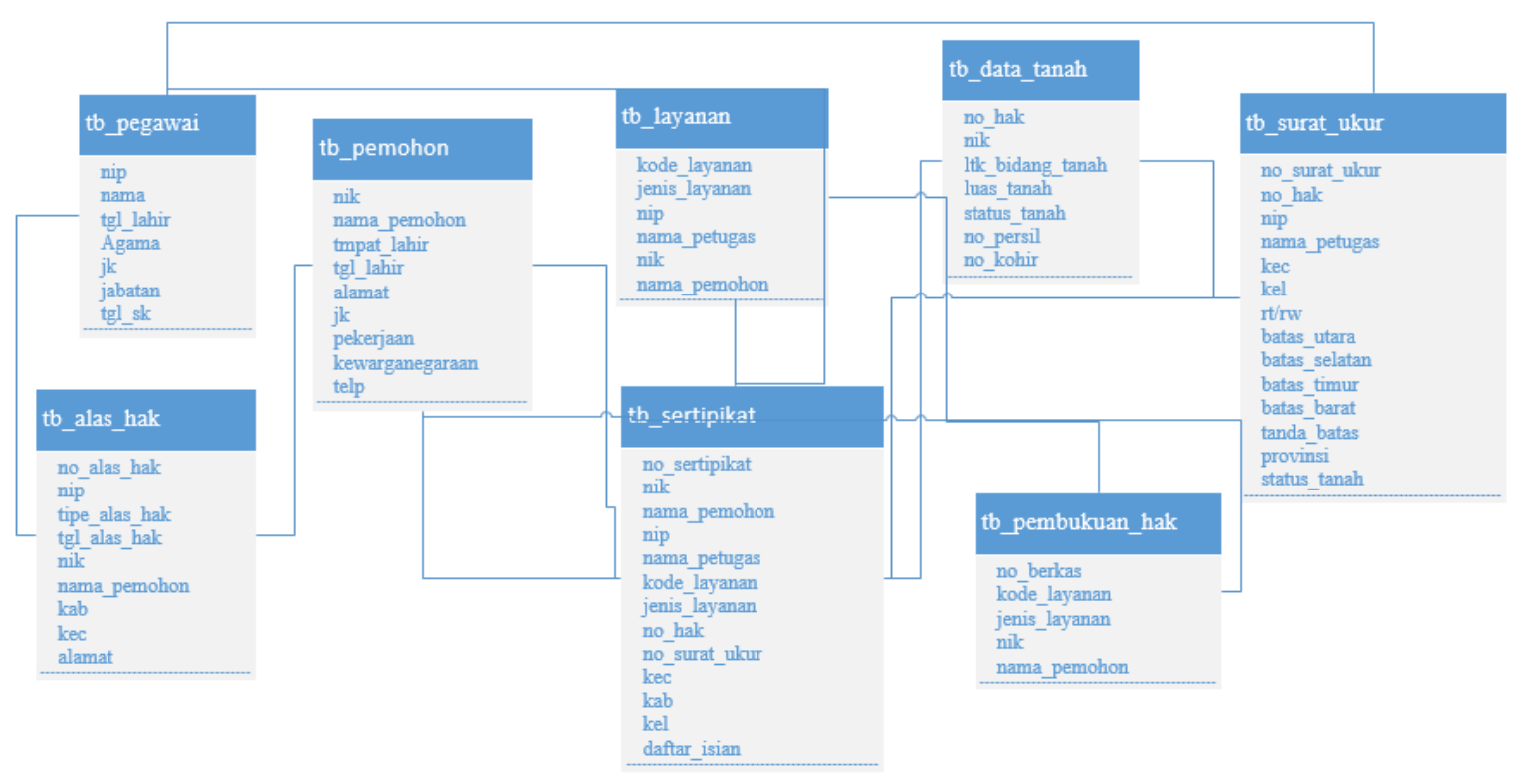

Gambar 3. Arsitektur Data

\section{D.5. Phase D: Technology Architecture}

Pada fase ini dilakukan identifikasi terhadap sarana dan prasarana IT yang digunakan saat ini pada BPN Kota Pekanbaru, kemudian memodelka konfigurasi jaringan awal pada BPN Kota
Pekanbaru. Setelah itu membuat konfigurasi jaringan usulan pada Gambar 4 serta menentukan kebutuhan TI yang berupa, platform, konfigurasi hardware software menggunakan technology portofolio catalog. 


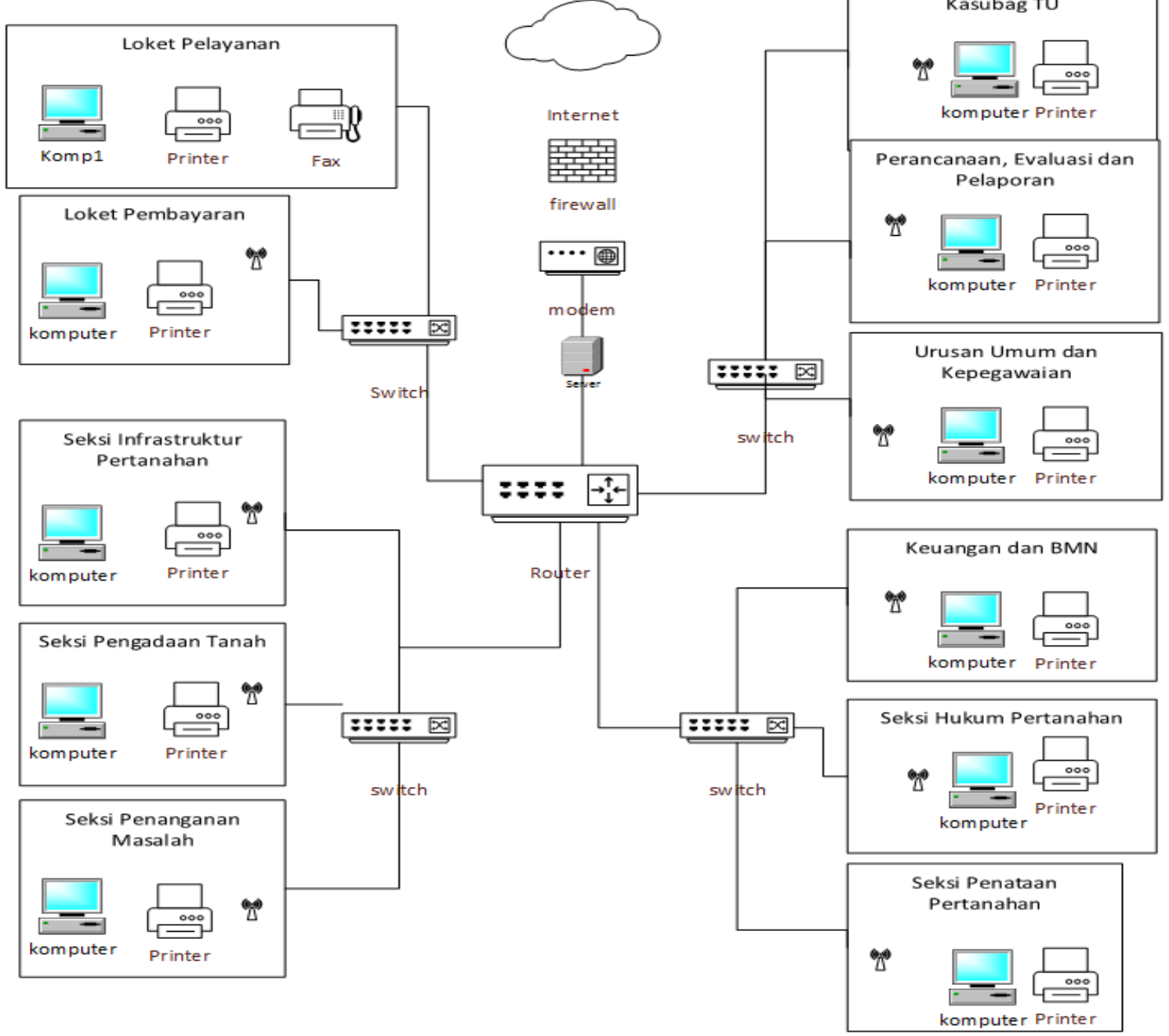

Gambar 4. Infrastruktur Jaringan Usulan

\section{D.6. Phase E: Opportunities and Solutions}

Pada fase ini akan dievaluasi model arsitektur yang telah dibangun saat ini dengan tujuan arsitektur target. Pertama dilakuka analisis kesenjangan atau gap analysis terhadap perancangan arsitektur meliputi: arsitektur bisnis, arsitektur data, arsitektur aplikasi dan arsitektur teknologi. Kemudian membuat matrik gap analysis terhadap arsitektur untuk mengetahui komponen mana yang harus dipertahankan dan harus diganti. Gap analysis dibuat berdasarkan arsitektur yang ada, pada arsitektur bisnis dapat dilihat pada Tabel 6, gap analysis arsitektur aplikasi dapat dilihat pada Tabel 7, gap analysis arsitektur data dapat dilihat pada Tabel 8 dan gap analysis arsitektur teknologi dapat dilihat pada Tabel 9.

Tabel 6. Gap Analysis Arsitektur Bisnis

\begin{tabular}{lll}
\hline $\begin{array}{l}\text { Arsitektur } \\
\text { Saat Ini }\end{array}$ & Analisa & $\begin{array}{l}\text { Arsitekture } \\
\text { Target }\end{array}$ \\
\hline Pelayanan & Adanya antrian & Sudah \\
Pertanahan. & panjang di loket & menggunakan TI \\
Pendaftaran & karena setiap & dalam menjalankan \\
Tanah. & harinya ada banyak & pelayanan \\
Penetapan & pemohon & pertanahan.
\end{tabular}

$\begin{array}{lll}\text { Hak Tanah. } & \text { pertanahan yang } & \\ & \text { datang. } & \\ & \text { Adanya aplikasi } & \\ & \text { KKP yang sudah } & \\ & \text { terintegrasi belum } & \\ & \text { mampu } & \\ & \text { mengurangi } & \\ & \text { padatnya antrian } & \\ & \text { pada loket. } & \\ & \text { Kurangnya fasilitas } & \\ & \text { IT untuk } & \\ & \text { menjalankan } & \\ \text { proses bisnis. } & \text { Adanya aplikasi } \\ \text { Pengukuran } & \text { Tidak } & \text { surat menyurat } \\ \text { Survey } & \text { derakomodasi } & \text { yang akan } \\ \text { Pemetaan } & \text { dengan baik } & \text { mengakomodasikan } \\ \text { Tanah } & \text { berkas-berkas surat } & \text { berkas surat } \\ & \text { perintah tugas } & \text { perintah tugas } \\ & \text { sehingga } & \text { kepada panitia yang } \\ & \text { menghambat } & \text { akan melaksanakan } \\ & \text { proses } & \text { pengukuruan tanah. } \\ & \text { pengukuran dan } \\ \text { Penerbitan } & \text { Pengecekan } & \text { survey. } \\ \text { dan } & \text { sertifikat hanya } & \text { Adanya } \\ \text { Penyerahan } & \text { pengembangan } \\ \text { Sertifikat } & \text { bisa dilakukan oleh } & \text { aplikasi yang dapat } \\ & \text { PPAT jika } & \text { digunakan untuk } \\ & \text { pemohon ingin } & \text { melakukan cek } \\ & \text { mengeceknya } & \text { berkas sertifikat }\end{array}$




\begin{tabular}{|c|c|c|}
\hline & $\begin{array}{l}\text { maka harus datang } \\
\text { ke kantor BPN } \\
\text { Kota Pekanbaru } \\
\text { dan antri di loket } \\
\text { cek sertifikat } \\
\text { online. }\end{array}$ & $\begin{array}{l}\text { tanah oleh } \\
\text { pemohon secara } \\
\text { online. }\end{array}$ \\
\hline Pemberdayaan & Kurangnya & Menyelenggarakan \\
\hline Masyarakat & $\begin{array}{l}\text { sosialisasi terhadap } \\
\text { masyarakat } \\
\text { mengenai tata cara } \\
\text { pelayanan } \\
\text { pertanahan dan } \\
\text { sistem informasi } \\
\text { yang ada saat ini } \\
\text { yang berfungsi } \\
\text { membantu proses } \\
\text { pelayanan } \\
\text { pertanahan. } \\
\text { Sehingga } \\
\text { masyarakat tidak } \\
\text { mengetahui adanya } \\
\text { sistem informasi } \\
\text { pelayanan dan } \\
\text { bagaimana cara } \\
\text { menggunakannya. }\end{array}$ & $\begin{array}{l}\text { kegiatan sosialisasi } \\
\text { yang berhubungan } \\
\text { dengan pelayanan } \\
\text { pertanahan dan } \\
\text { sistem informasi } \\
\text { pelayanan } \\
\text { pertanahan. } \\
\text { Adanya media } \\
\text { sosialisi yaitu } \\
\text { berupa vidio } \\
\text { animasi tata cara } \\
\text { pelayanan dan } \\
\text { penggunaan sistem } \\
\text { informasi pada } \\
\text { BPN Kota } \\
\text { Pekanbaru. }\end{array}$ \\
\hline Layanan & Kurangnya media & Layanan media \\
\hline Informasi & informasi & informasi seperti \\
\hline Masyarakat & $\begin{array}{l}\text { mengenai } \\
\text { pertanahan untuk } \\
\text { mendapatkan } \\
\text { informasi } \\
\text { pelayanan butuh } \\
\text { waktu 3-4 hari dan } \\
\text { harus mengantri } \\
\text { diloket informasi. } \\
\text { Web profil yang } \\
\text { menjadi media } \\
\text { informasi belum } \\
\text { mampu } \\
\text { menyediakan } \\
\text { informasi kepada } \\
\text { pemohon. }\end{array}$ & $\begin{array}{l}\text { website harus lebih } \\
\text { diperhatikan lagi } \\
\text { dan dilakukan } \\
\text { maintenance agar } \\
\text { pemohon dapat } \\
\text { mengakses } \\
\text { informasi } \\
\text { pelayanan } \\
\text { pertanahan. }\end{array}$ \\
\hline $\begin{array}{l}\text { Pengelolaan } \\
\text { Pengaduan }\end{array}$ & $\begin{array}{l}\text { Berkas pengaduan } \\
\text { yang telah terdaftar } \\
\text { secara online } \\
\text { maupun offline } \\
\text { tidak terkelola } \\
\text { dikarenakan } \\
\text { pengelolaan } \\
\text { pengaduan secara } \\
\text { terpusat tidak } \\
\text { dikelola } \\
\text { berdasarkan kantor } \\
\text { atau kota BPN } \\
\text { pemohon } \\
\text { mendaftar. }\end{array}$ & $\begin{array}{l}\text { Adanya layanan } \\
\text { pengaduan khusus } \\
\text { pemohon yang } \\
\text { mendaftar berkas } \\
\text { tanah nya di BPN } \\
\text { Kota Pekanbaru. }\end{array}$ \\
\hline
\end{tabular}

Tabel 7. Gap Analysis Arsitektur Aplikasi

\begin{tabular}{|c|c|c|}
\hline $\begin{array}{l}\text { Arsitektur Aplikasi } \\
\text { Saat Ini }\end{array}$ & Analisa & $\begin{array}{l}\text { Target } \\
\text { Arsitektur } \\
\text { Aplikasi }\end{array}$ \\
\hline $\begin{array}{l}\text { Sistem informasi } \\
\text { website profil dan } \\
\text { aplikasi sentuh } \\
\text { tanahku tidak } \\
\text { menampilkan } \\
\text { informasi sesuai } \\
\text { dengan fungsi } \\
\text { dilakukannya } \\
\text { pembuatan sistem } \\
\text { informasi. }\end{array}$ & $\begin{array}{l}\text { Melakukan } \\
\text { maintenance } \\
\text { dan update } \\
\text { informasi sesuai } \\
\text { dengan tujuan } \\
\text { dan fungsi } \\
\text { sistem } \\
\text { informasi. }\end{array}$ & $\begin{array}{l}\text { Semua sistem } \\
\text { informasi sudah } \\
\text { dapat diakses } \\
\text { dan } \\
\text { menampilkan } \\
\text { informasi } \\
\text { pelayanan } \\
\text { pertanahan. }\end{array}$ \\
\hline $\begin{array}{l}\text { Sistem informasi } \\
\text { yang ada belum } \\
\text { terintegrasi antara }\end{array}$ & $\begin{array}{l}\text { Melakukan } \\
\text { perbaikan } \\
\text { fasilitas }\end{array}$ & $\begin{array}{l}\text { Sistem informasi } \\
\text { terintegrasi. }\end{array}$ \\
\hline
\end{tabular}

\begin{tabular}{|c|c|c|}
\hline $\begin{array}{l}\text { satu sistem dengan } \\
\text { sistem yang lainnya. }\end{array}$ & $\begin{array}{l}\text { upgrade untuk } \\
\text { sistem } \\
\text { terintegrasi }\end{array}$ & \\
\hline $\begin{array}{l}\text { Proses pendaftaran } \\
\text { layanan pertanahan } \\
\text { masih manual dan } \\
\text { berkas belum } \\
\text { digital. }\end{array}$ & $\begin{array}{l}\text { Pengadaan } \\
\text { sistem } \\
\text { informasi } \\
\text { pendaftaran } \\
\text { online. }\end{array}$ & $\begin{array}{l}\text { Sistem informasi } \\
\text { pendaftaran } \\
\text { online. }\end{array}$ \\
\hline $\begin{array}{l}\text { Belum } \\
\text { menggunakan } \\
\text { sistem surat } \\
\text { menyurat terutama } \\
\text { surat tugas } \\
\text { pengukuran. }\end{array}$ & $\begin{array}{l}\text { Pengadaan } \\
\text { sistem } \\
\text { informasi surat } \\
\text { tugas. }\end{array}$ & $\begin{array}{l}\text { Sistem informasi } \\
\text { surat tugas. }\end{array}$ \\
\hline $\begin{array}{l}\text { Pengaduan } \\
\text { pertaanahan masih } \\
\text { terpusat di BPN RI. }\end{array}$ & $\begin{array}{l}\text { Pengadaan } \\
\text { sistem } \\
\text { informasi } \\
\text { pengaduan. }\end{array}$ & $\begin{array}{l}\text { Pengadaan } \\
\text { sistem informasi } \\
\text { pengaduan. }\end{array}$ \\
\hline
\end{tabular}

Tabel 8. Gap Analysis Arsitektur Data

\begin{tabular}{lll}
\hline $\begin{array}{l}\text { Arsitektur Data } \\
\text { Saat Ini }\end{array}$ & Analisa & $\begin{array}{l}\text { Target } \\
\text { Arsitektur Data }\end{array}$ \\
\hline $\begin{array}{l}\text { Terdapat duplikasi } \\
\text { data. }\end{array}$ & $\begin{array}{l}\text { Menganalissi } \\
\text { entitas data dan } \\
\text { merelasikannya. }\end{array}$ & $\begin{array}{l}\text { Tidak adanya } \\
\text { duplikasi data. }\end{array}$ \\
$\begin{array}{l}\text { Data yang ada } \\
\text { belum terintegrasi }\end{array}$ & $\begin{array}{l}\text { Upgrade } \\
\text { infrastruktur }\end{array}$ & $\begin{array}{l}\text { Database } \\
\text { terintegrasi. }\end{array}$ \\
sehingga proses & $\begin{array}{l}\text { data dan } \\
\text { pertukaran data } \\
\text { menjadi terhambar } \\
\text { dan terjadinya } \\
\text { duplikasi data. }\end{array}$ & database \\
terintegrasi. & \\
\hline
\end{tabular}

Tabel 9. Gap Analysis Arsitektur Teknologi

\begin{tabular}{|c|c|c|}
\hline $\begin{array}{l}\text { Arsitektur } \\
\text { Teknologi } \\
\text { Saat Ini }\end{array}$ & Analisa & $\begin{array}{l}\text { Target Arsitektur } \\
\text { Teknologi }\end{array}$ \\
\hline $\begin{array}{l}\text { Belum ada } \\
\text { user } \\
\text { management. }\end{array}$ & $\begin{array}{l}\text { Upgrade fasilitas } \\
\text { TI pocket } \\
\text { management. }\end{array}$ & $\begin{array}{l}\text { Tersedia user } \\
\text { management. }\end{array}$ \\
\hline $\begin{array}{l}\text { Belum ada } \\
\text { fasilitas IT } \\
\text { untuk antrian } \\
\text { pada loket } \\
\text { pelayanan. }\end{array}$ & $\begin{array}{l}\text { Upgrade fasilitas } \\
\text { TI antrian loket } \\
\text { pelayanan. }\end{array}$ & $\begin{array}{l}\text { Adanya fasilitas IT } \\
\text { antrian loket } \\
\text { pelayanan. }\end{array}$ \\
\hline $\begin{array}{l}\text { Bandwith } \\
\text { internet } \\
11 \mathrm{mbps} .\end{array}$ & $\begin{array}{l}\text { Upgrade fasilitas } \\
\text { TI untuk } \\
\text { meningkatkan } \\
\text { kapasitas daya. }\end{array}$ & $\begin{array}{l}\text { Bandwith internet } \\
250 \text { mbps. }\end{array}$ \\
\hline
\end{tabular}

\section{D.7. Blueprint}

Setelah melakukan perancangan enterprise architecture menggunakan TOGAF ADM pada sistem informasi pelayanan publik BPN Kota Pekanbaru, selanjutnya dibuat sebuah blueprint arsitektur dapat dilihat pada Gambar 5. Blueprint berisi ringkasan dari pembahasan perancanagan enterprise architecture yang terdiri dari: (1) Visi arsitektur meliputi arsitektur bisnis, aplikasi, data dan teknologi, (2) Lingkup enterprise architecture, (3) aktor yang terlibat, (4) Arsitektur Bisnis, (5) Arsitektur sistem informasi dan (6) Arsitektur Teknologi. 


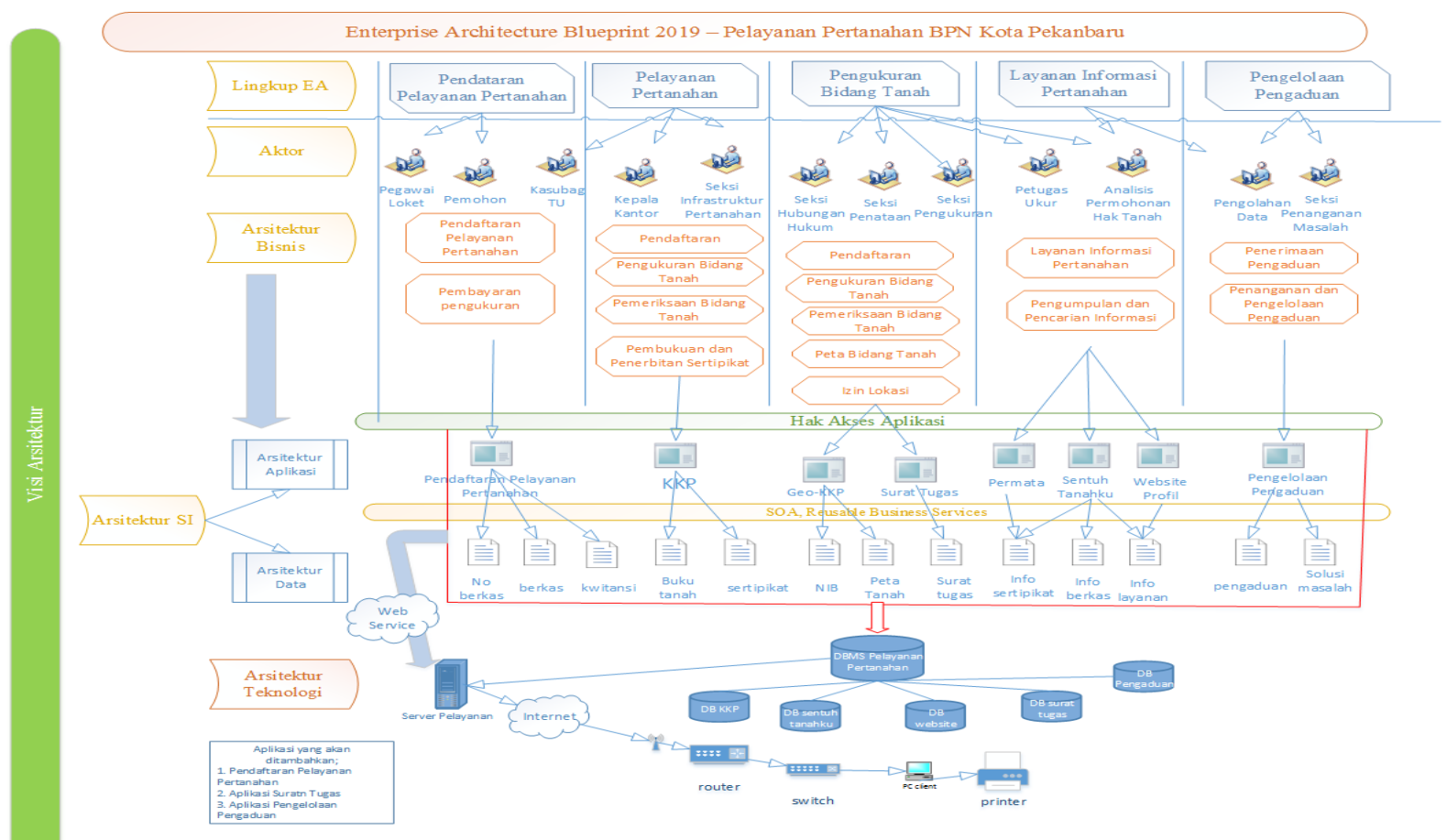

Gambar 5 Blurprint Arsitektur BPN Kota Pekanbaru

\section{E. KESIMPULAN}

Berdasarkan hasil dari analisis dan perancangan enterprise architecture sistem iinformasi pelayanan publik maka dapat disimpulkan bahwa BPN Kota Pekanbaru belum memiliki perencanaan arsitektur enterprise. Hasil dari perancangan arsitektur ini berupa blueprint (cetak biru) yang dapat digunakan untuk mempermudah proses pengembangan arsitektur pada BPN Kota Pekanbaru. Rancangan arsitektur sistem informasi menambahkan 3 (tiga) aplikasi tambahan yaitu: (1) sistem informasi pendaftaran pelayanan pertanahan; (2) aplikasi surat tugas; dan (3) aplikasi pengelolaan pengaduan.

\section{REFERENSI}

[1] Utomo. 2014. Pemodelan Arsitektur Enterprise Sistem Informasi Akademik Pada Perguruan Tinggi Menggunakan Enterprise Architecture Planning. Jurnal Teknik Mesin. Elektro dan Ilmu Komputer. Vol. 5. No. 1.

[2] Rendro Yunis dan Kusnanto. Surendro. 2009. Perancangan Model Enterprise Architecture Dengan Togaf Architecture Development Method.

[3] Ansgar Mondorf dan Maria Wimmer. 2017. Contextual Components of an Enterprise Architecture Framework for Pan-European eGovernment Services. Proceeding Hawai International Conference on System Sciences. ISSBN: 978-0-9981331-0-2.

[4] Dinh Dang dan Samuli Pekkola. 2017. Systematic Literature Review on Enterprise
Architecture in the Public Sector. Nol. 15, No. 2.

[5] R. D. Nugroho. 2017. Pelayanan Program Pendaftaran Mandiri Akta Tanah (Permata) Oleh Kementerian Agraria Dan Tata Ruang/Badan Pertanahan Nasional (Atr/Bpn) Kantor Pertanahan Kota Pekanbaru. Jurnal Ilmu Administrasi Publik FISIP Universitas Riau. Vol. 4. No. 2.

[6] Diogo Proenca dan Jose Borbinha. 2017. Enterprise Architecture: A Maturity Model Based on TOGAF ADM. IEEE 19th Conference on Business Informatics (CBI), Thessaloniki, Greece.

[7] Azizah. 2017. Inovasi Pelayanan Publik Pemerintah Daerah (Studi Tentang Penyelenggaraan Pelayanan Administrasi Terpadu Kecamatan (PATEN) di Kecamatan Gondanglegi Kabupaten Malang). hlm. 15.

[8] Nur Salim Rozak. Yuli Prasetyo dan Mulyanan Rahmat. 2017. Perancangan enterperise architecture pada fungsi operasional dan pelayanan publik perum bulog divre jawa barat menggunakan framework togaf adm. e-Proceeding $O f$ Engineering. Vol.4. No.3.

[9] Erwin Budi Setiawan. 2009. Pemilihan Ea Framework. Seminar Nasional Aplikasi Teknologi Informasi. hlm. ISSN: 1907-5022.

[10] Hendrik Kusbandono. 2014. Pemodelan Arsitektur Enterprise Menggunakan Togaf Adm Untuk Mendukung Sistem Informasi Proses Akademik Pada Universitas 
Jurnal Ilmiah Rekayasa dan Manajemen Sistem Informasi, Vol. 6, No. 1, Februari 2020, Hal. 6-15 e-ISSN 2502-8995 p-ISSN 2460-8181

Muhammadiyah Ponorogo. Jurnal Multitek Indonesia. Vol.8 No 1.

[11] Slamet Riyadi. Bambang Soedijono dan Armadyah Ambrowati. 2015. Pemodelan Enterprise Architecture Pelayanan di RSUD Murjani Sampit. Citec Journal. Vol. 2. No. 4.

[12] Desfray dan Raymond. 2014. TOGAF®," dalam Modeling Enterprise Architecture with TOGAF, Elsevier. 